\title{
Video-Based Android Application Development as an Educational Facility for E-Journal Users at the Library of Universitas Negeri Malang
}

\author{
Chamdi Fajar \\ Library Science Department \\ Universitas Negeri Malang \\ Malang, Indonesia \\ fajarchamdi@gmail.com
}

\author{
Moh. Safii * \\ Library Science Department \\ Universitas Negeri Malang \\ Malang, Indonesia \\ moh.safii@um.ac.id
}

\author{
Kusubakti Andajani \\ Indonesian Literature Department \\ Universitas Negeri Malang \\ Malang, Indonesia \\ kusubakti.andajani.fs@um.ac.id
}

\begin{abstract}
According to the data, there was a decrease access of e-journal by the academics of higher education institutions in Indonesia. Universitas Negeri Malang (UM) Library as a college library also had a few internal problems of students in terms of library e-journal service user education. This problem can be solved by developing the user education of library e-journal service. There are a lot of data which mention the opportunities that can be used as basic research and development include $90 \%$ of the world community accessing videos, $45.3 \%$ of internet users in Indonesia like video content, and $75 \%$ of gadget users in Indonesia use devices with the Android operating system. This research method used research and development methods of Rapid Application Development (RAD) model which consists of four stages, namely (1) planning needs, (2) user design, (3) construction, and (4) switching. The results of research and development show, educational products for Android-based ejournal users are considered "very valid" by media experts, material experts, and practitioners with a percentage of $95.77 \%$ in the media aspect, and $87.5 \%$ in the material aspect. The product was also rated "valid" by students with a percentage of $82.07 \%$ in the media aspect, and $83.04 \%$ in the material aspect. Product revision is done after the validity test and field trial based on suggestions by the validator and students. The main features of the video-based android application are three ejournal user education videos of UM Library consist of ejournal service video, video of access way electronic journal services, and video of searching methods on e-journal sites. The benefits of product are (1) helping the UM Library in order to introduce e-journal services, (2) encouraging users to access ejournal services as a reference source for writing quality scientific work, (3) helping UM Library participate in the development of era.
\end{abstract}

Keywords-academic library, android-based application, user education, library socialization, e-journals service

\section{INTRODUCTION}

According to the data, there was a decrease in access to ejournals, especially access made by the academics of tertiary institutions from 2009 to 2017. In 2009, the percentage of journal accesses was 32\% (Istiana, 2012). In 2017, the percentage of journal access was 26\% (Kemenristekdikti, 2017).

The causes of the low access of e-journals include: (1) English language ability factors by users, the most of the information in e-journals was in English; (2) E-journal access service factor, there were some paid article that cannot be downloaded; (3) There weren't socialization from the library (Mustati, 2013). Other than that, the implementation of user education in some university libraries hadn't yet been developed and carried out professionally, because it only done at the basic level, namely the installation of signs or infographics in the library (Rangkuti, 2014).

Beside that, there were internal and external factor in Universitas Negeri Malang (UM) Library in terms of utilizing e-journal services (Kartika, 2016). Previously, UM Library have ever tried to socialize e-journal services including banner installation, e-journal usage training activities on February 23, 2016 and on 12th February, 2019 (Perpustakaan Universitas Negeri Malang, 2019).

Based on the results of interviews with UM students and UM librarians as informants, it is known that there were some problem of user education of e-journal service in UM Library. According to the librarian, the problem was the short duration of library socialization activities because it was carried out in each faculty during the orientation period of new students. Short duration results in the delivery of material not too complete. UM students also argued that the delivery of material at the time of library socialization activities on PKKMB can't be remembered.

According to the results of interviews with UM students, there were several problems related to the use of e-journal services in the UM Library including (1) some users were unaware of the existence of e-journal services, (2) some library users knew the existence of e-journal services but have never tried because of lack of information, (3) constraints in interest of users who knew the existence of e-journaling services but have a poor first experience due to lack of information resulting in failure to logged in on e-journal pages, (4) constraints on the use of English in journal articles accessed at e-journal service.

Based on the results of the interview, the main problem was the internal constraints of students, namely the lack of clear information that impacts the interest in accessing ejournals. Therefore, the development of e-journal user education can be done by adjusting the characteristics of students. Based on survey data regarding internet usage activities, $90 \%$ of the world community likes video-based 
content (Kemp, 2020). Whereas in Indonesia, $45.3 \%$ of internet users like video-based content (APJII, 2018). Based on the media or devices used to access content on the Internet, data shows that $75.3 \%$ of users use devices with the Android operating system (Kemp, 2019).

Research and development of video-based android applications as a means of e-journal user education in UM Library is important as a solution to the problems of user education in UM Library regarding e-journal services. Until now, there weren't similar application product developed before, and this is an excellent opportunity to develop a product that addresses these user education problems.

\section{RESEARCH METHODS}

The research approach used research and development of the Rapid Application Development (RAD) model. This model was a developing model with several stages including (1) planning needs, (2) user design, (3) construction, and (4) transition (Sarosa, 2017).

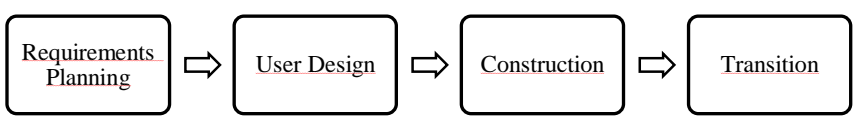

Fig. 1. The Steps of Rapid Application Development Model (Source: Sarosa, 2017)

This research requires primary data that was information about the user needs of android-based application and information in the form of numbers from the results of testing android-based application products. Primary data obtained through interviews using interview guide instruments and the distribution of product effectiveness test questionnaires using questionnaire.

Product testing conducted was a product effectiveness test consisting of validation tests and field trials. The product validation test was carried out by media expert validator, material expert validator, and a library practitioner to determine product validity. After the validation test, the product corrected that based on suggestions and / or comments in the form of input from the validator before a field trial conducted. Field trials conducted by UM students to find out the student's assessment of the product. After the field trial, the product improved based on suggestions and / or comments in the form of input from participating UM students.

This study used two data analysis techniques. The first analysis technique used to analyze the results of the interview using Miles and Huberman model. This technique was chosen because the interview data was in the form of information about user needs from the informants. The second analysis technique used to analyze the results of product effectiveness tests using non-parametric statistical inferential techniques. This technique was chosen because the product effectiveness test results data was in number form to made generalized (Sugiyono, 2018).

\section{RESEARCH AND DEVELOPMENT RESULTS}

Based on the results of interviews with informants, researchers argued that video-based android applications as a means of education for e-journal users needed by UM Library librarians and UM students. Based on the above problems, researchers developed a video-based android application product from interviews with informants related to user needs using the RAD development stage. The product tested for effectiveness which consists of product validation and field trials.

Data analysis of product effectiveness test results was carried out by providing a score for each question point on the questionnaire, calculating the total score obtained from each validator, then calculating the valid value with the following formula (Centaury, 2015).

\section{$\mathbf{p}=\mathbf{f} / \mathbf{n} \times 100 \%$}

$$
\begin{array}{ll}
\text { Explanation }: & \mathrm{p}=\text { validity value; } \\
\mathrm{f}=\text { score obtained; } \\
\mathrm{n}=\text { maximum score. }
\end{array}
$$

The results of calculating the validity value analyzed by looking at the categories of learning device validity. The following is a table of categories of learning device validity (Centaury, 2015).

TABLE I. VALIDITY CATEGORY

\begin{tabular}{ll}
\hline Interval & Category \\
\hline $0 \%-20 \%$ & Very Invalid / Horrible \\
$21 \%-40 \%$ & Invalid / Rough \\
$41 \%-60 \%$ & Invalid / Rough \\
$61 \%-80 \%$ & Valid / Good \\
$81 \%-100 \%$ & Very Valid / Very Good \\
\hline
\end{tabular}

\section{A. Step I: Requirements Planning}

On this step, developer identified user needs like prepared the tools, note sheets, recorder, instrument of interview until took the data from informants. The selected informants were librarian of serial service of UM Library, and UM students. The interview can be done / finished if there was saturated data or repetition of the same answers by informants. During the interview process, the researcher recorded each answer from the informants using some tools like note sheets and a recorder.

\section{B. Step 2: User Design}

On this step, developer analyzed data from interview before, designed user interface and system flow of application using figma prototyping tools, and then evaluated by validators. Figma was free online-based prototyping tools. The aim of this step was to obtain the feedback from validators and define system requirements.

Researcher used Miles and Huberman model to analyze the data. This model included data reduction, data display, and conclusion drawing. The result of data analyzes had explained on introduction part that used for the base of this research. After the prototype design was finished, the researcher evaluated it by the validators including media expert, material expert and library practitioner.

\section{Step 3: Construction}

On this step, developer repaired the design based on the feedback from validators, built the prototype into the mobile application format, and then evaluated it by field trial to UM students. The result of the field trial then evaluated using statistical analysis model. Statistical result show that the 
application product needs to be repair. Because of that, developer repaired it based on feedback from the result of field trial.

\section{Step 4: Transition}

On this step, developer launched the application product to google play store. Application can be downloaded for free and ready to used.

\section{E. Validation Test Results of Aspects of Android-Based Learning Media}

In the aspect of Android-based video learning media, the validation test results show the total score obtained by the media expert validator was 105 and the total score obtained by the practitioner validator was 83 . The maximum number of media expert scores was 4 (maximum score of answers) x 27 (number of questions) $=108$, while the maximum number of practitioners' score was 4 (maximum score of answers) x 22 (number of questions) $=88$. The percentage of validation test results by media experts was $(105 / 108) \times 100 \%=97.22 \%$; while the percentage of validation test results by practical was $(83 / 88) \times 100 \%=94.32 \%$. The average percentage of products on aspects of Android-based learning video media was $95.77 \%$. This percentage included in the category of learning device validity "very valid". This means that the product was feasible to be able to carried out field trials, but previously the product was repaired in accordance with input from the validator.

\section{F. Validation Test Results for Aspects of E-Journal Users Education Material}

In the aspect of e-journal user education material, the results of the validation test show the total score obtained by the material expert validator was 88 and the total score obtained by the practitioner validator was 81 . The maximum number of material expert scores was 4 (maximum score of answers) $\times 28$ (number of questions) $=112$, while the maximum number of practitioners' score was 4 (maximum score of answers) $\times 21$ (number of questions) $=84$. The percentage of validation test results by media experts was $(88 / 112) \times 100 \%=78.57 \%$; while the percentage of validation test results by practical was $(81 / 84) \times 100 \%=96.43 \%$. The average percentage of products in the educational material aspects of e-journal users was $87.5 \%$. This percentage included in the category of learning device validity "very valid". This means that the product was feasible to be able to carried out field trials, but previously the product was repaired in accordance with input from the validator.

\section{G. Field Trial Results for Android-Based Learning Media Aspects}

In the aspect of video media, the score obtained from the results of the field trial was 2206 . The maximum number of scores was 4 (maximum score of answers) x 48 (number of participants) $\times 14$ (number of questions) $=2688$. The percentage of results of field trials by UM students was $(2206 / 2688) \times 100 \%=82.07 \%$. This percentage included in the category of validity of the learning tool "very good". This means that the application product has met the criteria for publication, but needs to be repaired based on students feedback.

\section{H. Field Trial Results for E-Journal Users Education Aspects}

In the aspect of e-journal user educational material, the score obtained from the results of the field trial was 1435 . The maximum number of scores is 4 (maximum score of answers) $\mathrm{x} 48$ (number of participants) $\times 9$ (number of questions) $=$ 1728. Percentage of results of field trials by UM students was $(1435 / 1728) \times 100 \%=83.04 \%$. This percentage included in the category of validity of the learning tool "very good". This means that the application product has met the criteria for publication, but needs to be repaired based on students feedback.

\section{Product Description}

The product developed was a video-based android application product as a means of e-journal user education in Universitas Negeri Malang (UM) Library included the operational manual of the application. This application product named E-JOURNAL user education. The video shown was a type of learning video that aims to deliver learning material about the user education of UM Library ejournal services. Video content included (1) an urgency video for accessing UM Library e-journal services, (2) video information for UM Library e-journal services, (3) videos for accessing UM Library e-journal services, and (4) videos about search / search techniques used in the search field on e-journal pages.

The media used to display educational videos of e-journal users using YouTube has set visibility to be displayed only through the E-JOURNAL user education application. This media was chosen to avoid application file sizes that are too large. The E-JOURNAL user education application can be operated optimally on an android device with minimum specifications namely (1) android 4.1 (Android Jelly Bean), (2) 2GB RAM, (3) 720 x 1280 pixels screen resolution, (4) internet connection.

\section{J. Application User Interface}

The E-JOURNAL user education application consists of 8 pages, named (1) application opening, (2) homepage menu, (3) flow feature of accessing e-journals, (4) important features of e-journal, (5) application guidance menu, (6) sipadu menu, (7) information menu, (8) translator menu. Following is the appearance of the application.

\section{- Application Opening Page}

The application opening page was the page that first displayed when the user runs the E-JOURNAL user education application that has been downloaded and installed. Following is the appearance of the page.

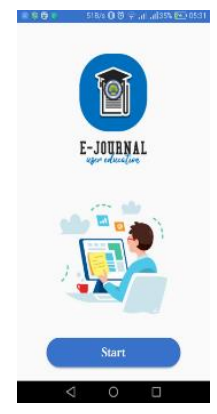

Fig. 2. Application opening page interface of E-JOURNAL user education 


\section{- Homepage Menu}

The homepage menu was the page that appears after pressing the "start" button on the opening page of the previous application. This page was the main page that contained the main features of the E-JOURNAL user education application. The following was the appearance of the home menu page.

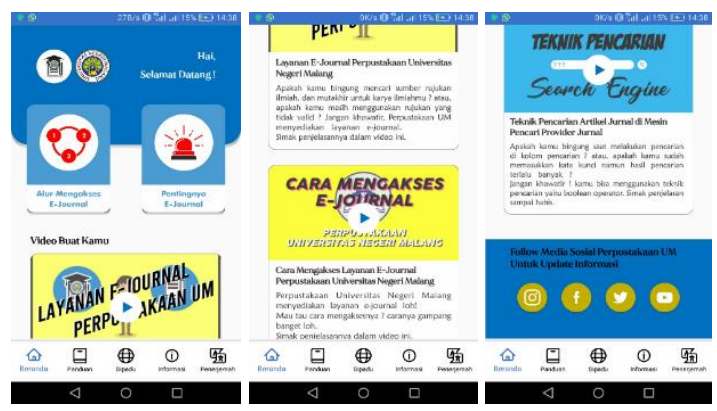

Fig. 3. Homepage menu interface of E-JOURNAL user education

- Page Flow Feature Accessing E-Journal

The flow feature of accessing e-journal located on the homepage of the E-JOURNAL user education application homepage. This feature contained a step by step description for users who will access e-journal services. The flow feature of accessing e-journals has the following page views.
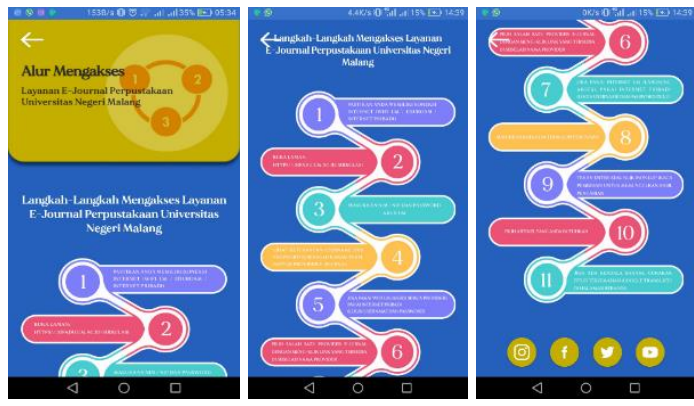

Fig. 4. Page flow feature accessing interface

\section{- Page Feature Importance of E-Journal}

The important feature of e-journal located on the home page of the E-JOURNAL user education application. This feature contained videos about the importance of accessing e-journal services. The important features of e-journal have the following page views.
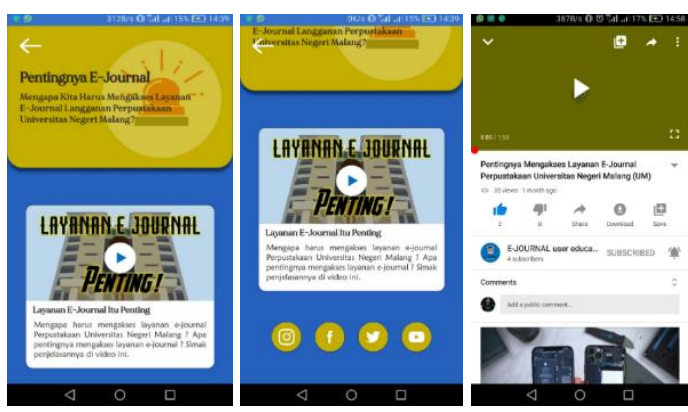

Fig. 5. Page Feature Importance of E-Journal Interface
- Application Guidance Menu

The application guide menu was a page that contained the application operational manual. The book can be opened and read directly through the E-JOURNAL user education application. The following was the appearance of the application guide menu page.
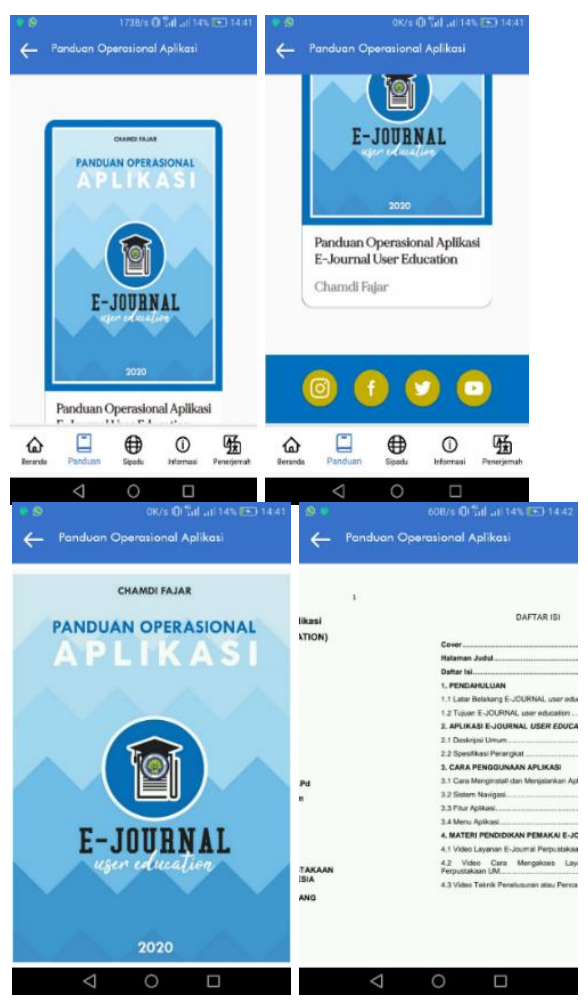

Fig. 6. Application Guidance Menu Page Interface

\section{- Sipadu Menu}

Sipadu menu was a menu connected via a browser that is used to access the UM Integrated Library Information System (sipadu) page. The page contained information about e-journal providers who are subscribed to UM Library along with a username and password to access it. The following was the appearance of the sipadu menu page.

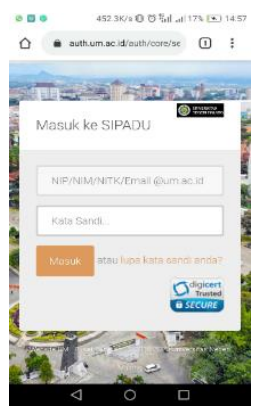

Fig. 7. Sipadu Menu Interface

- Information Menu

Information menu was a page that contained a menu of information about the application, UM Library website, share applications, and application rating. The following was the appearance of the information menu page. 


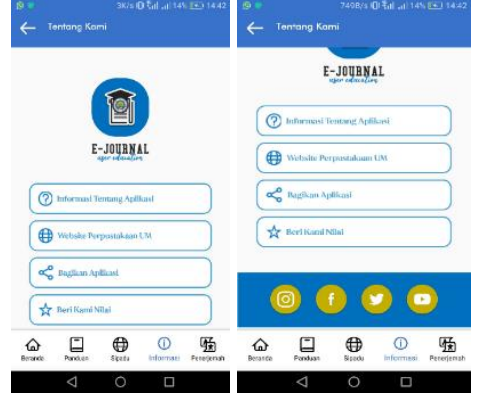

Fig. 8. Information Menu Interface

\section{- Translator Menu}

Translator menu was a page that connected to the google translate page through a browser. This menu used to translate foreign language articles into Indonesian easily and efficiently. The following was the appearance of the translator's menu page.

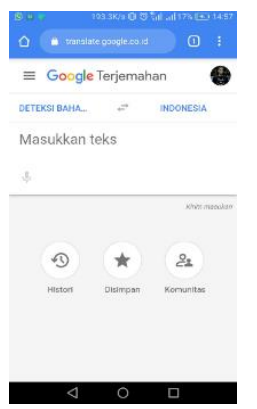

Fig. 9. Translator Menu Page Interface

\section{CONCLUSIONS}

\section{A. Product Review}

The product developed was a video-based android application as an educational as a means of e-journal user education in Universitas Negeri Malang (UM) Library named E-JOURNAL user education. The purpose of the product developed was to provide orientation or introduction to the UM Library e-journal service to UM academics using videobased android application. Educational material for UM Library e-journal users delivered via video media which can only be accessed through the E-JOURNAL user education application available on the Google Play Store. The e-journal user education videos consist of three videos included UM Library e-journal service videos, videos on how to access UM Library e-journal services, and video search techniques on ejournal pages subscribed to UM Library. In addition, there was one additional video that featured of the application, which was a video of the importance of the UM Library e-journal service.

E-JOURNAL user education application products had been tested for product effectiveness consisting of expert validation and field trials. The expert validation test was carried out by the media expert validator, the material expert validator, and the practitioner validator, while the field trial was conducted by the field trial participants namely UM students. The results of the validation of experts and practitioners as well as field trials indicate that the EJOURNAL user education application product included in the category of very valid or very good in both media and material aspects validator, and the practitioner validator, while the field trial was conducted by the field trial participants namely UM students.

\section{B. Suggestion}

Suggestions given by researchers so that the products can be more widely known, namely by using several promotional mixes, including (1) personal selling by communicating products to consumers who visit directly, (2) mass selling by communicating products using social media, (3) sales promotion with persuasive communication during library orientation in new student orientation activities.

Through this E-JOURNAL user education application product, it is expected that users can find out about e-journal services at UM Library, users can take advantage of e-journal services to the maximum, users can produce quality scientific work by using e-journal services as referral source.

\section{REFERENCES}

[1] APJII, "Penetrasi \& Profil Perilaku Pengguna Internet Indonesia 2018 (Penetration \& Indonesian Internet User Behavior Profiles 2018)" Survei, Jakarta, 2018, retrieved from https://apjii.or.id/survei

[2] Centaury, B, "Pengembangan Perangkat Pembelajaran Fisika Berbasis Inkuiri pada Materi Alat Optik dan Indikator Dampak Terhadap Kompetensi Siswa Kelas X SMA (Development of Inquiry-Based Physics Learning Tools on Optical Instrument Material and Indicators of Impact on Competence of Class X SMA Students)", Padang, 2015, retrieved from http://ejournal.stkip-pgrisumbar.ac.id/index.php/JRFES/

[3] Kartika, E. D., "Pemanfaatan E-journal Dikti oleh Pemustaka Perpustakaan Universitas Negeri Malang (Utilization of Dikti's Ejournal by Library Users of the Universitas Negeri Malang)", Malang, 2016, retrieved from http://karya-ilmiah.um.ac.id/

[4] Kemenristekdikti, "Pedoman Publikasi Ilmiah (Scientific Publication Guidelines)", Yogyakarta, 2017, retrieved from http://wibirama.staff.ugm.ac.id/

[5] Kemp, S., "The State of Digital in April 2019: All The Numbers You Need to Know", New York, 2019, retrieved htttps://wearesocial.com/

[6] Kemp, S., "Digital Around The World in April 2020", New York, 2020, retrieved htttps://wearesocial.com/

[7] Mustati, "Pemanfaatan E-Journal Dalam Memenuhi Kebutuhan Informasi Ilmiah di Kalangan Civitas Akademik Universitas Hasanuddin (Utilization of E-Journal in Meeting the Needs for Scientific Information among the Academic Community of Hasanuddin University)", Makassar, 2013, retrieved from http://journal.unhas.ac.id/

[8] Rangkuti, L. A., "Pentingnya Pendidikan Pemakai (User Education) di Perpustakaan Perguruan Tinggi (The Importance of User Education in the College Libraries)", Medan, 2014, retrieved from http://repository.uinsu.ac.id/

[9] Sarosa, S., Metodologi Pengembangan Sistem Informasi (Information Systems Development Methodology), Jakarta: Indeks, 2017.

[10] Sugiyono, Metode Penelitian Kuantitatif, Kualitatif, dan R\&D (Quantitative Research Methods, Qualitative, and R\&D), Bandung: Alfabeta, 2018.

[11] Perpustakaan Universitas Negeri Malang, "Universitas Negeri Malang Bekerjasama dengan iGroup Asia Pacific Ltd. Menyelenggarakan Sosialisasi Penggunaan dan Akses E-Journal Springer Nature (Universitas Negeri Malang Collaborates with iGroup Asia Pacific Ltd. Organized the Socialization of the Use and Access of the Springer Nature E-Journal)", Malang, 2019, retrieved from http://lib.um.ac.id/index.php 